\title{
Potential Risk of Virus Carryover by Fabrics of Personal Protective Gowns
}

\author{
lyoko Katoh ${ }^{1 *}$, Fuminori Tanabe ${ }^{2}$, Hirotake Kasai ${ }^{2}$, Kohji Moriishi ${ }^{2}$, Noriko Shimasaki ${ }^{3}$, \\ Katsuaki Shinohara ${ }^{4}$, Yukiko Uchida ${ }^{5}$, Tomoko Koshiba ${ }^{6}$, Soichi Arakawa ${ }^{7}$ and \\ Michiko Morimoto ${ }^{8}$
}

\begin{abstract}
${ }^{1}$ Oral Health Science Research Center, Kanagawa Dental University, Yokosuka, Japan, ${ }^{2}$ Faculty of Medicine, University of Yamanashi, Chuo, Japan, ${ }^{3}$ Influenza Virus Research Center, National Institute of Infectious Diseases, Tokyo, Japan, ${ }^{4}$ Division of Biosafety Control and Research, National Institute of Infectious Diseases, Tokyo, Japan, ${ }^{5}$ Faculty of Health and Welfare, Takasaki University of Health and Welfare, Takasaki, Japan, ${ }^{6}$ Faculty of Fashion Science, Bunka Gakuen University, Tokyo, Japan, ${ }^{7}$ Sanda City Hospital, Sanda, Japan, ${ }^{8}$ Faculty of Health and Welfare Science, Okayama Prefectural University, Soja, Japan
\end{abstract}

Personal protective gowns and coveralls are classified based on barrier efficiency that validates protection from fluid penetration under certain pressures. Materials standardized in this system have been found suitable for emergency medical practices confronting highly contagious diseases. Nevertheless, adhesion of blood, and body

OPEN ACCESS

Edited by:

Victor C. W. Hoe,

University of Malaya, Malaysia

Reviewed by:

Yuke Tien Fong,

Singapore General

Hospital, Singapore

Caterina Ledda,

Università degli Studi di Catania, Italy

${ }^{*}$ Correspondence:

lyoko Katoh

katoh.iyoko@kdu.ac.jp

Specialty section: This article was submitted to Occupational Health and Safety,

a section of the journal

Frontiers in Public Health

Received: 27 August 2018 Accepted: 30 April 2019

Published: 22 May 2019

Citation:

Katoh I, Tanabe F, Kasai H, Moriishi K, Shimasaki N, Shinohara K, Uchida Y,

Koshiba T, Arakawa S and Morimoto M (2019) Potential Risk of Virus Carryover by Fabrics of Personal

Protective Gowns.

Front. Public Health 7:121.

doi: 10.3389/fpubh.2019.00121 fluids from virus-infected patients to the surface of protective clothing still imposes a risk of pathogen transmission in the process of doffing, or undressing. We performed a small-scale experiment to test the possibility of infectious virus carryover on the surface of different fabrics used in commercially available protective gowns. Application of a lentivirus vector that expresses green fluorescent protein allowed easy monitoring of infectious viral loads on fabrics. Results indicate that fabrics of level-3 surgical gowns serve better to reduce virus transmission compared to fabrics of chemical protective clothing with the same or higher barrier efficiency. Analysis of sliding angles provided indexes of fluid repellency, which were inversely related to virus carryover potentials. Droplets of infectious body fluids may easily roll off fabrics with water-repellent finishing. Thus, virus carryover is a measurable risk factor to be considered for better choice of personal protective clothing.

Keywords: personal protective equipment, infection, surgical gown, fabric, health care workers, virus, water repellency, sliding angle

\section{INTRODUCTION}

Personal protective equipment (PPE) is essential to guard healthcare workers (HCW) in emergency departments and in wards with highly contagious patients. Gowns and coveralls, as other components of PPE, are designed to prevent transmission of pathogens contained in the blood and body fluids of patients $(1,2)$. Presently, PPE is classified by barrier efficiency that certifies protection from penetration of fluids, bacteria, and bacteriophage under defined pressures. However, selection of isolation gowns involves consideration of various attributes including classification standards, guidelines, and effectiveness (3). As inferred from the Ebola and SARS outbreaks, availability in the facility, tolerance to distress in the protective gowns, and conditions of patients are also important issues (4). In fact, overheating was found as a major concern in HCW who worked with PPE $(5,6)$. 
Importantly, the process of removing PPE has the highest risk of contact transfer of viruses from the PPE surface to the skin of $\mathrm{HCW}(4,7,8)$. Many reports have highlighted careful instructions of removal procedures to $\operatorname{HCW}(6,8)$. Furthermore, application of repellent finish was thought to reduce the risk of body fluid carryover by the gowns (1). In contrast to the emphasis given on barrier efficiency, which is categorized as levels 1-4 by standards such as ANSI/AAMI PB70 and ISO16603/16604, the impact of fluid repellency has been poorly documented. We designed a small-scale biological experiment to detect the infectious viral loads on the surfaces of commercially available PPE fabrics. In this challenging study, all experiments were conducted with priority for qualitative index, but not for "evaluation" or "judgment" on statistical analyses.

\section{MATERIALS AND METHODS}

\section{Fabrics}

The sources and features of the fabrics examined in this study are listed in Table 1. Product $S$ is a single layer of polyethylene, and is usually used as a cover on nurse uniforms. $\mathrm{H}$ and $\mathrm{J}$ are sterile disposable surgical gowns that meet the AAMI level 3 standard. Coveralls V, M, and $\mathrm{C}$ are non-sterile disposable protective clothing that meet ISO standards of liquid and bacteriophage barrier function. Fabric pieces ( $7 \mathrm{~mm}$ square) were cut out using sterilized tools in the safety cabinet. Most PPE fabrics of this dimension provided a sufficient area for droplet attachment, and could be kept flat throughout the experiment. Fabrics of unsterilized gowns (S, V, M, and C) were exposed to UV-light for $10 \mathrm{~s}$ on each side.

\section{Green Fluorescence Protein (GFP)-Lentivirus}

Experiments were performed in biosafety level-2 facilities under the protocols approved by Institutional Biosafety Committee of University of Yamanashi. For experimental safety and easy counting of infected cells, we used a self-inactivating lentiviral empty vector that produces Aequorea coerulescens GFP in infected cells. The virus is referred to as GFP-lentivirus in this study. Lenti-X 293T cells were transfected with pLVSINacGFP1-C1 plasmid and the Lentiviral High Titer Packaging Mix (Clontech). At $48 \mathrm{~h}$, the culture supernatant was harvested, centrifuged, and further clarified by passing through a membrane filter (pore size $0.45 \mu \mathrm{m})$. Aliquots of the virus suspension $(\sim 5 \times$ $10^{5}$ infectious units $/ \mathrm{mL}$ ) were frozen at $-80^{\circ} \mathrm{C}$ until use.

\section{Small-Scale Virus Carryover Experiment}

A graphic summary of this experiment is shown in Supplementary Figure 1. HeLa cells used as virus recipient cells were plated $\left(8 \times 10^{4}\right.$ cells/well, $\left.96 \mathrm{~mm}^{2}\right)$ in a glassbottomed 24-well plate (SensoPlate, Greiner) $24 \mathrm{~h}$ before virus infection. A droplet $(40 \mu \mathrm{L})$ of GFP-lentivirus-containing fluid (culture medium, D-MEM, supplemented with $10 \%$ fetal bovine serum and antibiotics) was placed on a plastic plate and immediately a fabric piece was placed on the droplet so that the surface was in contact with the droplet for $1 \mathrm{~min}$. The fabric was then carefully lifted with a fine-tipped tweezer. The fluid attached to the fabric was retrieved in culture medium (200 $\mu \mathrm{L}$ ), and the residual medium on the fabric was precipitated in a $1.5 \mathrm{~mL}$ centrifuge tube by spinning at $1,000 \mathrm{rpm}$ for $10 \mathrm{~s}$. HeLa cells were incubated with the retrieved virus suspension containing $8 \mu \mathrm{g} / \mathrm{mL}$ of Polybrene (Santa Cruz Biotechnology). At $44 \mathrm{~h}$ post-infection, cells were incubated with fresh medium containing Hoechst $33342(2 \mu \mathrm{g} / \mathrm{mL})$ for an additional $1 \mathrm{~h}$.

\section{Microscopic Observation and Cell Counting}

Three fields $\left(\sim 10 \mathrm{~mm}^{2}\right)$ of blue (nuclei stained with Hoechst 33342) and green (cells infected with GFP-lentivirus) fluorescence were imaged for each well using the Keyence BZ-9000 fluorescence microscope. Cells were counted using the BZ-II Dynamic Cell Count Ver. 1.01 program in the BZ-9000 Analysis Software.

\section{Analysis of Cytotoxicity and Anti-virus Activity}

The surface of the fabric piece was incubated with complete culture medium $(200 \mu \mathrm{L})$ in the wells of a 24 -well plate for $24 \mathrm{~h}$ at $37^{\circ} \mathrm{C}$. To analyze the cytotoxicity of materials eluted from the fabric surface, HeLa cells were cultured with the fabric-incubated medium for $24 \mathrm{~h}$, and the amount of ATP was measured using an ATP assay kit (Abcam, ab83355). We also tested the fabricincubated medium for GFP-lentivirus infectivity.

\section{Measurement of Sliding Angles}

We analyzed the sliding angles of fluid droplets on the fabrics as described previously (9). A droplet $(50 \mu \mathrm{L})$ of culture medium containing $10 \%$ serum was placed on the fabric $(148 \times 210 \mathrm{~mm})$ fixed to a tilting stage (DMo-501SA, Kyowa, Japan). The stage was inclined $(2 \%$ s) until the droplet began to slide, or roll off. Sliding angle was defined here as the stage angle at $0.5 \mathrm{~s}$ ( $1^{\circ}$ incline) before the droplet began to slide. The droplet volume required for measurement was determined be $50 \mu \mathrm{L}$ using fabrics $\mathrm{H}$ and $\mathrm{M}$.

\section{RESULTS}

\section{Virus Carryover by the Fabrics}

We applied GFP-lentivirus produced by pLVSIN-acGFP1-C1 in this study, because the virus particles infect cells only once, and do not spread through the cultures. When GFP-lentivirus particles in a $40 \mu \mathrm{L}$ droplet of culture medium (with $10 \%$ serum) infected HeLa cells directly, $\sim 2,300$ cells ( $\sim 30 \%)$ were found GFP-positive in a background of 7700 Hoechst-stained nuclei in areas of $10 \mathrm{~mm}^{2}$ (Figure 1, upper panels). In the virus carryover experiments, fabric pieces were placed on GFPlentivirus-containing droplets so that the fabric surfaces came into contact with the fluid (Supplementary Figure 1). The fluid retrieved from each fabric piece was used to infect $\mathrm{HeLa}$ cells and GFP-expressing cells were assessed. Interestingly, the GFP-positive cell numbers varied from one fabric to another. For example, an increased number of GFP-positive cells were detected with fabric $\mathrm{C}$ (bottom) than with fabric J (middle).

We counted the cells with blue (Hoechst 33342) and green (GFP) fluorescence using the cell counting program (Figure 2). 
TABLE 1 | Fabrics tested in this study.

\begin{tabular}{|c|c|c|c|c|c|}
\hline Fabric & $\begin{array}{l}\text { Standards: } \\
\text { barrier efficiency }\end{array}$ & Materials & $\begin{array}{l}\text { Repellent } \\
\text { finish }\end{array}$ & Suggested application & $\begin{array}{l}\text { Manufacturer, } \\
\text { product }\end{array}$ \\
\hline S & ANSI AAMI ${ }^{\mathrm{a}}$ Level-1 $^{-1}$ & Polyethylene & & Protective cover & Saraya $^{f}$, Plastic gown \\
\hline $\mathrm{H}$ & ANSI AAMI ${ }^{\mathrm{a}}$ Level-3 & $\begin{array}{l}\text { Non-woven polypropyrene, } \\
\text { spunbond/meltblown/spunbond }\end{array}$ & $\sqrt{ }$ & Surgical gown & Hogy Medical $^{f}$, Salem \\
\hline J & AAMI $^{\mathrm{a}}$ Level-3 $^{-}$ & $\begin{array}{l}\text { Non-woven polypropyrene, } \\
\text { spunbond/meltblown/spunbond, } \\
5 \text { layers }\end{array}$ & $\sqrt{ }$ & Surgical gown & $\mathrm{JMS}^{f}$, Opegown III \\
\hline V & $\begin{array}{l}\text { EN ISO } 22610 a^{b} \text { Class- } 1 \text {, } \\
\text { ISO } 16603^{\text {C }} \text { Class-3 }\end{array}$ & $\begin{array}{l}\text { Flash spun high-density } \\
\text { polyethylene }\end{array}$ & & $\begin{array}{l}\text { Chemical protective } \\
\text { garment }\end{array}$ & DuPont, Tyvek (400) \\
\hline M & $\begin{array}{l}\text { EN ISO22610 }{ }^{\mathrm{b}} \text { Class-4, ISO } \\
16604^{\mathrm{d}} \text { Class-4 }\end{array}$ & $\begin{array}{l}\text { Laminated fabric } \\
\text { (Polypropylene+ } \\
\text { microporous film) }\end{array}$ & & $\begin{array}{l}\text { Pharmaceutical } \\
\text { manufacturing, agriculture } \\
\text { and veterinary services }\end{array}$ & XINYUANg, Metec Plus-T \\
\hline C & $\begin{array}{l}\text { EN } 14126 \text { Type 4B } \\
\text { ISO16603 } \\
\text { C } \text { Class }-6^{\mathrm{e}} \\
\text { ISO16604 }\end{array}$ & $\begin{array}{l}\text { Fabric } \mathrm{V} \text { with polymer } \\
\text { coating }\end{array}$ & & $\begin{array}{l}\text { Protection against chemical } \\
\text { and biological hazards }\end{array}$ & DuPont, Tychem C \\
\hline
\end{tabular}

astandard for isolation gowns.

${ }^{b}$ Bacterial penetration breakthrough time (Class-1, $\leq 15 \mathrm{~min}$ ) (Class-4, >45 min).

${ }^{c}$ Resistance to penetration of blood and body fluids (Class-3, $>3.5 \mathrm{kPa}$ ) (Class-6, $>20 \mathrm{kPa}$ ).

${ }^{d}$ Resistance to penetration of blood borne pathogens (bacteriophage $\varphi$ X174) (Class-4, $>7 \mathrm{kPa}$ ) (Class-6, $>20 \mathrm{kPa}$ ).

${ }^{e}$ Protective clothing against radioactive contamination.

${ }^{f} J a p a n$.

gChina.

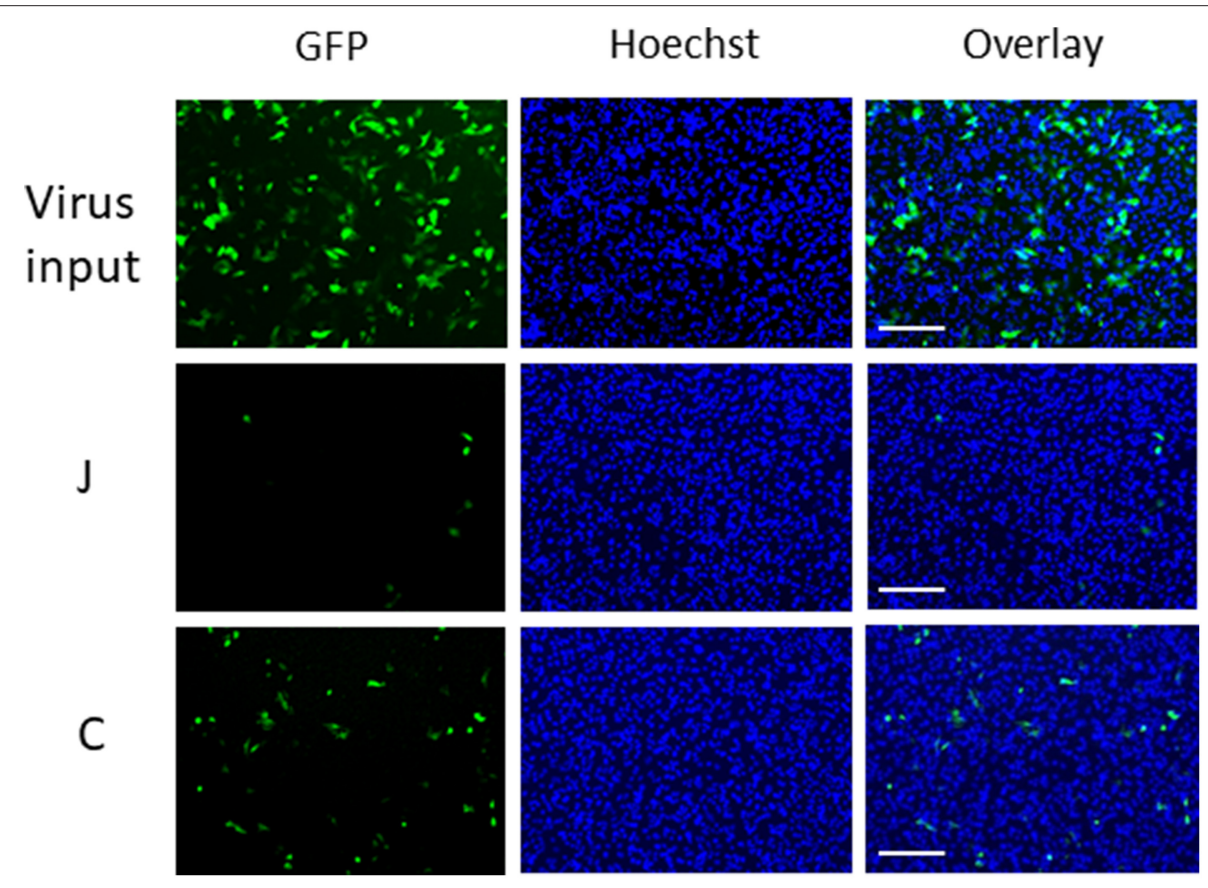

FIGURE 1 | Microscopic observation of cells infected with GFP-lentivirus transferred by fabrics J and C. Each panel corresponds to a $1 / 9$ part of each view field (10 $\mathrm{mm}^{2}$ ) in which GFP-positive cells and Hoechst-stained cells were counted. Scale bars indicate $200 \mu \mathrm{m}$.

The data obtained by our biological experiments in small sample size are presented by scatterplots, but not by bar graphs (10). The entire cell counts did not differ significantly among the tested fabrics, $\mathrm{H}, \mathrm{J}, \mathrm{V}, \mathrm{M}$, and $\mathrm{C}$, and were similar to the counts with the virus-containing $40 \mu \mathrm{L}$ droplet (virus input) (Figure 2B). A small fraction (1-2\%) of the GFP-lentivirus in the droplet was transferred by fabrics $\mathrm{H}$ and $\mathrm{J}$ (Figure 2A). Surprisingly, more efficient virus transfer (5-30\%) was observed with V, M, and C. The virus-containing fluid was the most adhesive to fabric $\mathrm{C}$ with the strongest barrier efficiency (Table 1). These results suggest 


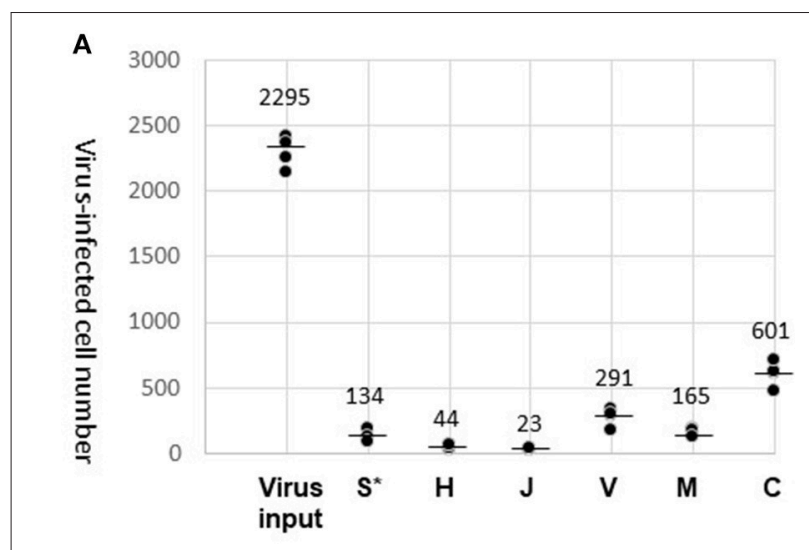

B

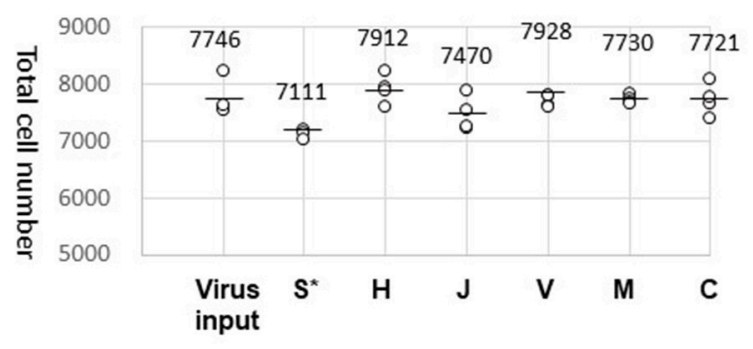

FIGURE 2 | Results of virus carryover experiments. (A) Virus-infected cell number. GFP-positive cell counts (average of three different view fields of 10 $\mathrm{mm}^{2}$ ) were obtained for four wells and plotted (dark dots). The mean of the four well counts is indicated by a bar. In addition to the virus carryover by the test fabrics ( $, H, J, V, M$, and $C$ ), the entire virus load (Virus input) in the droplet $(40 \mu \mathrm{L})$ were also examined. ( ${ }^{*}$ After attachment of the droplet, fabric $S$ was directly submerged in the well of HeLa cell culture). (B) Total cell number. Hoechst-stained cells were counted and plotted in the same way as in (A) (circles).

that virus carryover potentials increase in the order: $\mathrm{H}, \mathrm{J}<\mathrm{M}$ $<\mathrm{V}$, C. We performed this experiment in quadruplicate and repeated three times to obtain comparable results.

Fabric S, a soft polyethylene material, was easily crumpled and could not tolerate the virus recovery process. Alternatively, fabric $S$ was directly submerged in the medium of HeLa cell culture after the virus attachment. Results obtained by this procedure were plotted in the $S^{*}$ column for reference only (Figure 2A). The Hoechst-stained cell counts were decreased by $\sim 10 \%$, where a certain amount of virus transfer by fabric $S$ was evident by the detection of GFP-positive cells.

\section{Absence of Anti-viral or Cytotoxic Materials on the Fabric Surface}

We considered the possibility that chemicals eluted from the fabric might have interfered with the GFP-lentivirus infection. The fabric surface was exposed to culture medium for $24 \mathrm{~h}$ to allow soluble materials to dissolve into the medium. A constant amount of GFP-lentivirus was diluted in the fabricexposed medium to infect HeLa cells. At the end of the infection period (45h), GFP-positive cells were counted. As a result,

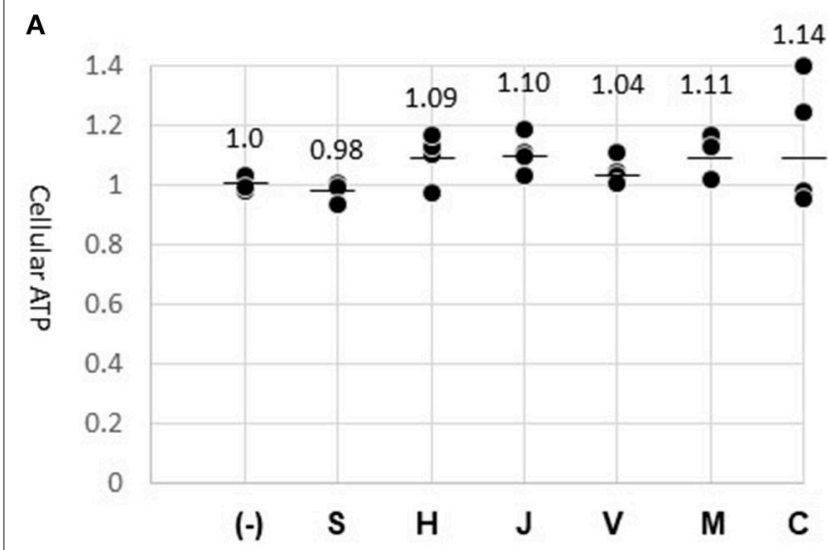

B

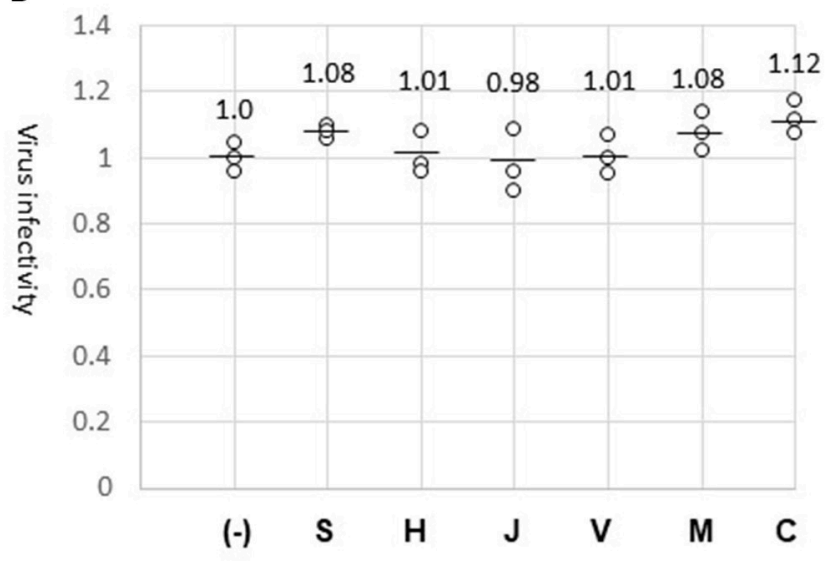

FIGURE 3 | Absence of cytotoxic or anti-virus material on fabric surfaces. (A) Cellular ATP. Cells were incubated for $24 \mathrm{~h}$ with the media previously exposed to the surface of fabrics (S, H, J, V, M, and C) or the normal medium (-). ATP amount in the cell lysate was measured in four wells (dark dots) and indicated in relation to the control experiment (1.0). The mean of four measures is shown by a bar. (B) GFP-lentivirus stock was diluted 1:10 in the fabric-exposed medium for infecting HeLa cells. At $45 \mathrm{~h}$, virus-infected cells were counted in three wells. The virus-infected cell numbers are indicated (circles) in relation to the control experiment (1.0).

the virus infected cell number was not altered by the fabrics tested, confirming that the virus infection process was not affected by materials on the fabrics (Figure 3B). In parallel, cells were cultured in the same medium without the virus, and were analyzed for ATP amounts. Cellular ATP production was not significantly altered (Figure 3A), suggesting that the fabrics had no cytotoxic effect. Thus, the differences in GFP-lentivirus transfer among the fabrics (Figure 2A) were not caused by materials eluted from the fabrics. These experiments with the fabric-elution media were done two times without causing a significant deviation.

\section{Measurement of Sliding Angles}

We attempted to evaluate fluid-repellency as opposed to fluid-adhesion, using an alternative technique other than the above-described biological method. Sliding angles, also termed 


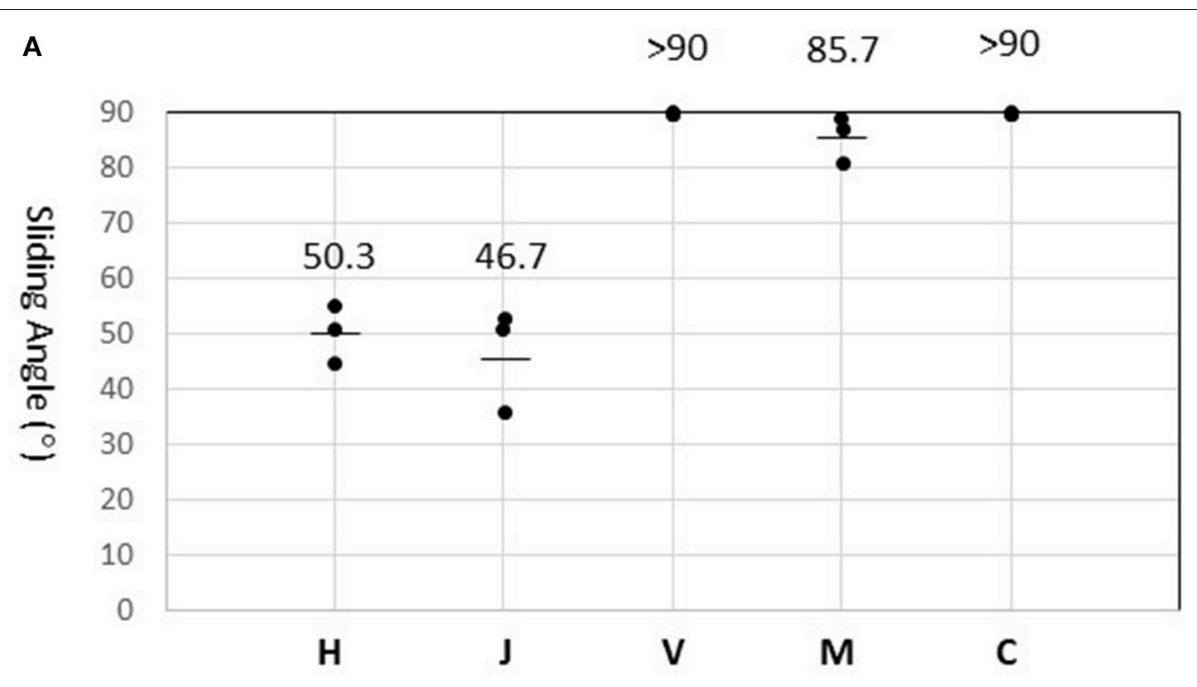

B

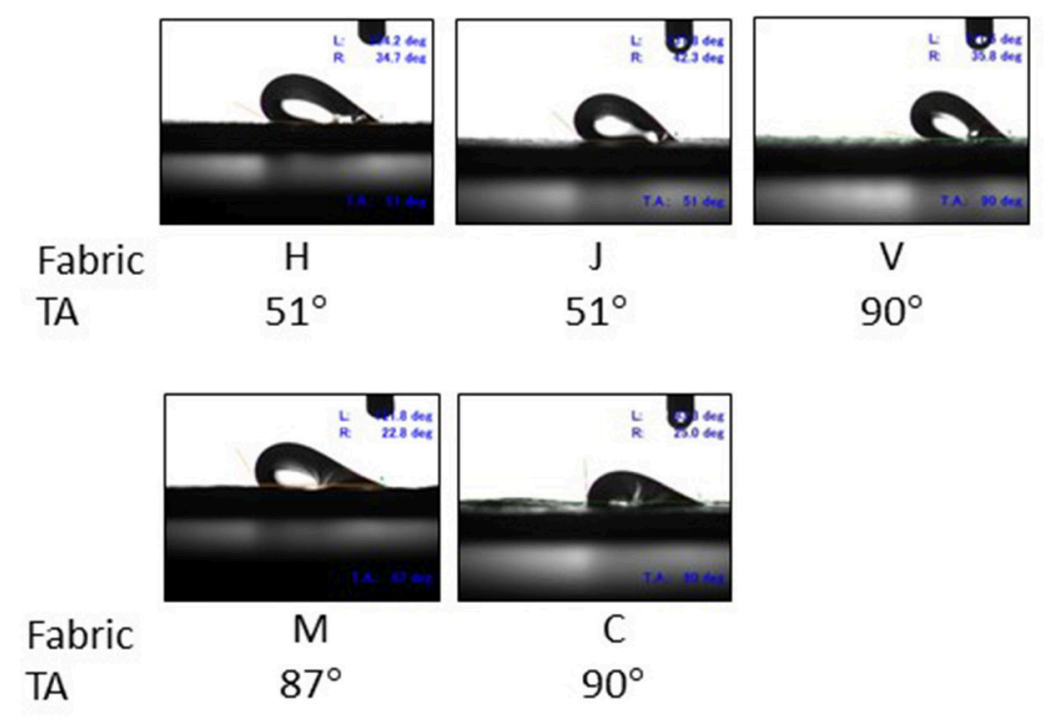

FIGURE 4 | Measurement of sliding angles. (A) Sliding angle is here defined as the stage angle at 0.5 second (corresponding to tilt angle of $1^{\circ}$ ) before the droplet began to slide. Values $\left(^{\circ}\right.$ ) obtained in three experiments are shown by dots. The mean of three measures is indicated as a bar for fabrics $\mathrm{H}$, $\mathrm{J}$, and $\mathrm{M}$. On fabric $\mathrm{V}$ and $\mathrm{C}$, the droplet did not slide even when the tilt angle (TA) reached $90^{\circ}$ (as indicated by $>90$ ). (B) Snapshots of the droplet at the moment of sliding angle measurement. Experiments were recorded using a movie camera fixed to the stage. The monitor also displayed the tilt angle (TA), advancing contact angle (left, L), and receding contact angle (right, $R$ ).

"shedding angles" and "roll-off angles," indicate the waterrepellent properties of textiles $(9,11)$.

Sliding angles determined for fabrics $\mathrm{H}$ and $\mathrm{J}\left(50.3^{\circ}\right.$ and $46.7^{\circ}$, respectively) were significantly lower than that of fabric $\mathrm{M}\left(87.5^{\circ}\right.$ ) (Figure 4A). Surprisingly, the fluid droplet did not roll-off fabric $\mathrm{V}$ or $\mathrm{C}$, even when the stage was tilted to $90^{\circ}$ (Figure 4B). Thus, the test fabrics showed stronger fluidrepellency in the order: $\mathrm{H}, \mathrm{J}>\mathrm{M}>\mathrm{V}, \mathrm{C}$. This result is consistent with the fact that fabrics $\mathrm{H}$ and $\mathrm{J}$ have a water-repellent finish, whereas the others do not (Table 1). Furthermore, fluid repellencies were inversely related to virus carryover potentials (Figure 2).

\section{DISCUSSION}

Fabrics of personal protective gowns were tested for the possibility of GFP-lentivirus carryover. Adhesion of viruscontaining fluid was found to vary from one fabric to another. Interestingly, surgical gown fabrics of class-3 $(\mathrm{H}$, J), as determined by the standards of ANSI AMI, showed significantly decreased virus adherence property compared to chemical protective coveralls with the same (V) or higher barrier efficiencies (M, C). Fluorocarbon-based finishes are commonly used for surgical operation gowns made of fabrics $\mathrm{H}$ and $\mathrm{J}$ (1). These types of gowns may offer good choices for HCW 
who care for patients in epidemic/pandemic incidences, under the conditions where excessive pressures against the gowns are not anticipated.

SARS and MERS coronaviruses survive on dry surfaces for days or weeks depending on the experimental methods and environments (12). Influenza viruses have relatively shorter survival times, but can remain infectious at least for hours (12). The GFP-lentivirus used here represents HIV and is related to HTLV, both of which are blood borne viruses. Virus adhesion to PPE surfaces thus imposes a considerable threat to HCW, especially in doffing procedures when they leave contagious wards. Even ordinary hospital gowns were found as carriers of bacteria and viruses $(13,14)$.

Substantial refinement is necessary to develop more feasible and reliable assay methods suitable for statistical analyses. Furthermore, we noted workable modifications to the present system: (i) composition of test fluids (blood, other body fluids, or their substitutes); (ii) adhesion time; (iii) virus retention time on the fabrics; (iv) the use of different types of viruses, etc.

Sliding angles serve as good indicators of water-repellency in superhydrophobic textiles $(9,11)$. The technique is simple and more reliable than other conventional techniques such as contact angle determination, and may be applicable to PPE fabric evaluation. It is emphasized that the sliding angle measurements for the five different PPE fabrics directly corresponded to their virus carryover potentials.

In conclusion, we showed that PPE fabrics can mediate transmission of infectious viruses. Virus carryover potential varies among different fabrics, reflecting the fluid-repellency

\section{REFERENCES}

1. Kilinc FS. A review of isolation gowns in healthcare: fabric and gown properties. J Eng Fiber Fabr. (2015) 10:18090. doi: $10.1177 / 155892501501000313$

2. Shimasaki N, Hara M, Kikuno R, Shinohara K. A highly sensitive assay using synthetic blood containing test microbes for evaluation of the penetration resistance of protective clothing material under applied pressure. Biocontrol Sci. (2016) 21:141-52. doi: 10.4265/bio.21.141

3. Kilinc Balci FS. Isolation gowns in health care settings: laboratory studies, regulations and standards, and potential barriers of gown selection and use. Am J Infect Control. (2016) 44:104-11. doi: 10.1016/j.ajic.2015.07.042

4. Hewlett AL, Varkey JB, Smith PW, Ribner BS. Ebola virus disease: preparedness and infection control lessons learned from two biocontainment units. Curr Opin Infect Dis. (2015) 28:343-8. doi: 10.1097/QCO.0000000000000176

5. Potter AW, Gonzalez JA, Xu X. Ebola response: modeling the risk of heat stress from personal protective clothing. PLoS ONE. (2015) 10:e0143461. doi: 10.1371/journal.pone.0143461

6. Den Boon S, Vallenas C, Ferri M, Norris SL. Incorporating health workers' perspectives into a WHO guideline on personal protective equipment developed during an Ebola virus disease outbreak. F1000Res. (2018) 7:45. doi: 10.12688/f1000research.12922.2

7. Casanova L, Alfano-Sobsey E, Rutala WA, Weber DJ, Sobsey M. Virus transfer from personal protective equipment to healthcare employees' skin and clothing. Emerg Infect Dis. (2008) 14:1291-3. doi: 10.3201/eid1408.080085

8. Fischer WA II, Wohl DA. Confronting ebola as a sexually transmitted infection. Clin Infect Dis. (2016) 62:1272-6. doi: 10.1093/cid/ciw123

9. Zimmerman J, Seeger S, Reifler FA. Wader shedding angle: a new technique to evaluate the water-repellent properties of superhydrophobic surfaces. Textile Res J. (2009) 79:1565-70. doi: 10.1177/0040517509105074 but not barrier efficiency. Body fluid repellency is measurable by biological and surface technologies and may provide a preferable index for the selection and improvement of PPE.

\section{AUTHOR CONTRIBUTIONS}

MM, SA, KS, and YU: study conception and design. NS, TK, $\mathrm{YU}$, and KM: provision of materials and analysis tools. IK, HK, and FT: acquisition of data. IK, HK, FT, and MM: analysis and interpretation of data. IK: drafting of manuscript. FT and MM: critical revision.

\section{FUNDING}

This work was supported by a Grant-in-Aid for Scientific Research (A) (JSPS KAKENHI Grant Number JP15H02581).

\section{ACKNOWLEDGMENTS}

We thank Masakazu Kato, Kyowa Interface Science, Co., Ltd., Niiza-city, Japan, for valuable suggestions regarding determination of sliding angle.

\section{SUPPLEMENTARY MATERIAL}

The Supplementary Material for this article can be found online at: https://www.frontiersin.org/articles/10.3389/fpubh. 2019.00121/full\#supplementary-material

10. Weissgerber TL, Milic NM, Winham SJ, Garovic VD. Beyond bar and line graphs: time for a new data presentation paradigm. PLoS Biol. (2015) 13:e1002128. doi: 10.1371/journal.pbio.1002128

11. Wang $\mathrm{H}$, Fang J, Cheng $\mathrm{T}$, Ding J, Qu L, Dai L, et al. Onestep coating of fluoro-containing silica nanoparticles for universal generation of surface superhydrophobicity. Chem Commun. (2008) 7:877-9. doi: 10.1039/B714352D

12. Otter JA, Donskey C, Yezli S, Douthwaite S, Goldenberg SD, Weber DJ. Transmission of SARS and MERS coronaviruses and influenza virus in healthcare settings: the possible role of dry surface contamination. J Hosp Infect. (2016) 92:235-50. doi: 10.1016/j.jhin.2015. 08.027

13. Pilonetto $M$, Rosa EA, Brofman PR, Baggio D, Calvario F, Schelp $\mathrm{C}$, et al. Hospital gowns as a vehicle for bacterial dissemination in an intensive care unit. Braz J Infect Dis. (2004) 8:206-10. doi: 10.1590/S1413-86702004000300003

14. Sidwell RW, Dixon GJ, Westbrook L, Forziati FH. Quantitative studies on fabrics as disseminators of viruses. V Effect of laundering on polioviruscontaminated fabrics. Appl Microbiol. (1971) 21:227-34.

Conflict of Interest Statement: The authors declare that the research was conducted in the absence of any commercial or financial relationships that could be construed as a potential conflict of interest.

Copyright (c) 2019 Katoh, Tanabe, Kasai, Moriishi, Shimasaki, Shinohara, Uchida, Koshiba, Arakawa and Morimoto. This is an open-access article distributed under the terms of the Creative Commons Attribution License (CC BY). The use, distribution or reproduction in other forums is permitted, provided the original author(s) and the copyright owner(s) are credited and that the original publication in this journal is cited, in accordance with accepted academic practice. No use, distribution or reproduction is permitted which does not comply with these terms. 